\title{
OBESITY: A CAUSATIVE RISK FACTOR OF BREAST CANCER
}

\author{
A. S. Roy, S. Basu, A. Bandyopadhyay \\ UNIVERSITY OF CALCUTTA, UNIVERSITY COLLEGE OF SCIENCE AND TECHNOLOGY, \\ KOLKATA, WEST BENGAL, INDIA
}

\begin{abstract}
Background. Obesity, a global health burden and one of the most deleterious diseases have substantially increased prevalence attributable to changing lifestyle of modern times. Persuasive evidence indicates obesity as an independent prognostic factor for developing malignancy in the form of breast cancer particularly in postmenopausal women.

Objective. This review aims to focus in comprehensive manner on the biochemical, hormonal and immunological pathways governing the obesity linked breast cancer so that potential treatments may be improvised consequently to provide a cure to this menace, threatening the lives of many.

Methods. Literature review of published materials that provide examination of recent or current literature on problem of obesity.

Results. Increased body fatness, mainly visceral adiposity may account for predisposing an obese individual to the risk of encountering cancer although the mechanisms for such cancers may vary depending upon the organ affected. Metabolic and biochemical alterations influencing obesity related carcinogenesis, consisting of heightened oxidative stress and bodily inflammation levels with the concomitant rise in pro-inflammatory cytokines are discussed. Pertinent references about elevated levels of serum insulin, insulin-like growth factor, sex steroids and the imbalance in adipokines (adiponectin and leptin) are included as well.

Conclusions. Persuasive evidence indicates obesity as an independent prognostic factor for developing malignancy in the form of breast cancer particularly in post-menopausal women. Generation of novel and effective therapeutic interventions for combating the ailment along with positive lifestyle modifications may be improvised consequently to provide a cure to this menace, threatening the lives of many.
\end{abstract}

KEY WORDS: obesity; breast cancer; lipotoxicity; adiponectins.

\section{Introduction}

Obesity is a major health problem of this century, characterized by excess accumulation of fat due to positive energy balance, resulting from energy intake that exceeds the energy expenditure [1]. A $15-20 \%$ of body fat for men and $25 \%$ of body fat for women are generally accepted as 'normal', but these are not essentially the optimal values, as a $10 \%$ to $20 \%$ of excess body fat over the usual values is generally considered to be "obesity" [2].

According to the World Health Organization (WHO) criteria, a BMI greater than or equal to $25 \mathrm{~kg} / \mathrm{m}^{2}$ is overweight, while obesity is defined as having a BMI equal to or higher than $30 \mathrm{~kg} / \mathrm{m}^{2}$. Obesity has been recognized, as a major risk factor for many cancers and, following tobacco use, may be the greatest modifiable cancer risk

Corresponding author: Dr. Amit Bandyopadhyay, B.Sc., M.Sc., Ph.D., Assistant Professor, Sports and Exercise Physiology Laboratory, Department of Physiology, University of Calcutta, University Colleges of Science and Technology, 92, A. P. C. Road, Kolkata: 700009, India.

E-mail: bamit74@yahoo.co.in factor $[3,4,5]$. The incidences of overweight and obesity is dramatically rising in most parts of the world, and is generally higher in women than in men [6]. Convincing data associate being overweight to the risk for various types of cancer as well as other chronic ailments, including cardiovascular disease, stroke and diabetes that are accountable to a large percentage of premature mortality $[7,8]$. The International Agency for Research on Cancer reviewed the literature on the involvement between excess body weight and cancer risk. They evaluated the available data as sufficient for a plausible connection with cancers of colon, female breast (postmenopausal), endometrium, kidney (renal cell), and oesophagus (adenocarcinoma). Preliminary information also exists to indicate a relationship with ancillary cancer [9, 10]. Specifically, obesity is related with a twofold increase in the risk of developing breast cancer in case of postmenopausal women while among premenopausal women it is associated with a reduced incidence [11]. Numerous 
interacting hormonal and metabolic pathways seem to underlie the link between being overweight and cancer, with insulin-resistance harbouring a major role. Since evidence is swelling that surplus body weight can also unfavourably influence cancer prognosis, obesity is a prime target for cancer management programs. This review explores the epidemiological and biological evidences concerning the linkage between excess body weight/obesity and particularly cancer in the breast in females, available from several accessible and thorough systematic literature surveys, along with a brief insight into the probable therapeutic interventions in vogue.

\section{Obesity Related Health Disorder}

Now a day's obesity and overweight are considered as main causative factors for several chronic diseases, most notably hypertension, type 2 diabetes, dyslipidaemia and coronary heart diseases, osteoarthritis and musculoskeletal disorders, fatty liver, gall stones, psychological disorders and psychosocial problems $[12,13]$. Direct relationship of obesity with mortality has also been documented [14]. Among its many health consequences, obesity is increasingly recognized as a risk factor for numerous malignancies, and the obesitycancer link has recently received much attention $[15,16]$. Sufficient evidences exist to link obesity with increased risk of colon cancer, postmenopausal breast cancer, endometrial cancer, renal cell cancer and adenocarcinoma of the oesophagus [17].

\section{Obesity and Cancer}

World Cancer Research Fund (WCRF) and American Institute for Cancer Research (AICR) concluded that obesity is an established risk factor for several cancers [18]. According to the reports of the last 25 years, obesity was found as a reason of approximately $14 \%$ of cancer deaths in men and up to $20 \%$ of deaths due to cancer in women [19]. Over this time-period, the commonness of overweight and obesity has gone up from $15 \%$ in 1980 to $35 \%$ in 2005 [20]. Recent investigations count on the fact that the total health onus of overweight and obesity may surpass that for cigarette smoking [20]. A major review of weight, physical activity, and cancer incidence by the International Agency for Research on Cancer (IARC) concluded in 2002 , that obesity was the aetiology of $11 \%$ of colon cancer cases, $9 \%$ of postmenopausal breast cancer cases, $39 \%$ of endometrial cancer incidences, $25 \%$ of kidney cancer cases, and $37 \%$ of oesophageal cancer incidences [17]. Addi- tionally, data from the American Cancer Society indicated, that overweight and obesity are connected to mortality from liver cancer, pancreatic cancer, non-Hodgkin's lymphoma, and myeloma [19].

Obesity and Cancer - General Mechanism General Mechanisms of Obesity and Cancer

The cause effect relationship of obesity and cancer are not well known. However, it is well established that it acts through obesity-related hormones, growth factors, multiple signalling pathways of calorie restriction and modulation of energy balance and inflammatory processes. These factors affect the promotion and progression of the cancer cells $[21,22,23,24$, 25, 26].

\section{Obesity and Breast Cancer}

Obesity has been marked as a noteworthy risk factor for breast cancer and the association varies depending upon the menopausal status in females. Breast cancer, as evident from the recent estimates is the most frequent type of cancer in women (28.9\% of all female incident cancers) of European population and is the second most common cancer overall $[27,28]$. Obesity is found to consistently rise in postmenopausal women by $30 \%-50 \%[29,30,31$, 32]. Breast cancer incidence varies considerably between developed and developing countries which may be attributed to nutritional factors and lifestyle behaviours due to different socioeconomic conditions and variation in ethnicity [33]. Literature clearly indicated the intimate association between obesity and breast cancer that might provide insight in exploring and identifying the various mechanisms involved in this process. Obesity linked breast cancer is multifactorial and involves a network of hormonal and metabolic pathways. Hence understanding the molecular and cellular mechanisms of the obesity-cancer link is imperative for developing potential therapeutics.

\section{Mechanisms Underlying Obesity Related Breast Cancer in Females \\ Bio-energetic homeostasis and cancer}

Metabolic parameters associated with body fatness might influence the bioenergetic balance of the cells and favour the expansion of cells with high anaerobic glycolytic capacity which is a characteristic feature regarding the bioenergetics adaptation of the cancer cells. This effect is termed as "Warburg effect" described by intense lipogenesis and glycolysis and low mitochondrial oxidative phosphorylation capacity even in the presence of adequate oxygen $[34,35]$. High blood glucose 
levels and hyperinsulinaemia, which is frequent in obese individuals, are thought to pose a selective advantage for the growth of such cells [36]. Increased risk of breast cancer attributed to higher energy intake has been reported in some research studies [37]. Adenosine 5 '-monophosphate activated protein kinase (AMPK) is a master sensor of cellular energy status that plays a key role in the regulation of whole-body energy homeostasis [38]. Recently, studies were conducted to examine targets such as AMP activated protein kinase (AMPK), mammalian target of rapamycin (mTOR), fatty acid synthase, deacetylase SIRT1 (sirtuin1) and epigenetic modulators as in nutrient sensing pathways coupled to insulin signalling have been hypothesized to participate in carcinogenesis [19].

Insulin, IGFs, IGFBPs and Insulin resistance - the interplay

Insulin resistance is a metabolic state characterized by a reduced response capacity to insulin by the muscle and liver cells [10]. Insulin resistance has been correlated to a subsequent compensatory excess production of pancreatic insulin leading to hyperinsulinaemia. Chronic hyperinsulinaemia in turn is related to carcinogenesis and linked to breast cancer [39, 40]. This can be explained in the light of the postulates of insulin-IGF hypothesis, which states that chronic hyperinsulinaemia decreases the production of Insulin like growth factor binding proteins (IGFBP1 and IGFBP2) that results in the subsequent rise of plasma levels of free IGF-1 with concomitant alterations in the cellular environment. Both insulin and IGF-1 are anabolic molecules that are capable of tumorogenesis by inhibiting apoptosis, stimulating cell proliferation and motility and being pro-angiogenic [41, 42, 43, 44]. High concentrations of circulating total IGF-1, a major determinant of free IGF-1 concentrations have been associated to an increased risk of premenopausal breast cancer [45]. However, the insulin-IGF hypothesis has two shortcomings. First, levels of total IGF-1 increases linearly with increased BMI but only up to a certain extent around $27 \mathrm{~kg} / \mathrm{m}^{2}$ and thereafter it reduces with further increase in weight [44]. Secondly, in overweight and/or obese individuals, who purposely lose weight (a presumed cancerprotective action), the total IGF-1 concentration tends to escalate the insulin-signalling pathway. This is very much relevant in case of cancer progression because both extracellular signal regulated kinase (ERK) and phosphatidyl ino- sitol-3 kinase (PI3K) pathways are triggered by activation of the insulin receptor (IR). Contrarily, over expression of the IR is evident in breast cancer patients [10,46, 47, 48,49]. Insulin and IGF-1 signal by mean of the Akt/PI3K/mTOR cascade for promotion of cell growth and proliferation, thereby inhibiting cell survival [50, 51]. This Akt/PI3K/mTOR cascade has emerged as a target of the obesity and cancer linkage and is activated by both insulin and IGF- 1 that are detected frequently at higher concentrations in the serum of the overweight and obese individuals, culminating $[52,53,54]$.

\section{Alterations in sex hormones}

Steroid hormones including oestrogen, progesterone, androgens and adrenal steroids are related with energy homeostasis and obesity related progression of different types of male and female cancers [55]. Obesity increases the risk of developing breast cancer after menopause and it has been indicated that up to $50 \%$ of postmenopausal breast cancers are linked to obesity [37]. Predisposing risk factors familiar in developing breast cancers are related to oestrogen e.g., early menarche, late menopause and hormone replacement therapy (HRT) $[56,57,58,59]$. Obesity and age has been ascertained as factors that may negatively influence the survival of patients with breast cancer $[60,61]$. Increased adiposity may influence sterol synthesis and metabolism of oestrogens. Obesity has been associated with increasing levels of oestrogen because of accelerated peripheral aromatization of adrenal androgens in adipose tissue among postmenopausal women, that can promote cell proliferation, have anti-apoptotic and pro-angiogenic effects $[62,63]$. In postmenopausal women, plasma levels of free oestradiol and testosterone are positively associated to breast cancer occurrence [64]. Studies revealed that the relationship between obesity and breast cancer risk in postmenopausal women might be justified by heightened levels of oestrogens, particularly bioavailable oestradiol $[65,66]$. Further, in case of postmenopausal women the link between body mass index (BMI) and risk of breast cancer has been strongly evident among women, who do not use hormone replacement therapy (HRT), compared to women, who have undergone HRT [67]. Some studies showed an inverse relationship between BMI and pre menopausal breast cancer and this may be supported by the fact that for pre menopausal women obesity is linked with a higher frequency of anovulatory cycles and with reduced levels 
of circulating sex steroids [67]. Another dimension to the association between BMI and breast cancer is mammographic density, the latter being negatively correlated with BMI. For adjustment of mammographic density, estimates for BMI, cancer risk rise [68].

\section{Lipotoxicity}

Cancer cells exhibit accentuated de novo lipogenesis by means of elevated fatty acid synthase (FASN), an enzyme responsible for synthesizing endogenous fatty acids, that may be modified and packaged into structural lipids required for cell division [69]. Both obesity and cancer cell-derived lipolytic enzymes produce free fatty acids for the tumour to supply structural as well as oncogenic lipid signalling molecules such as platelet activating factor (PAF), sphingosine 1-phosphate (S1P), lysophosphatidic acid (LPA) and prostaglandins [70]. Elevated FASN enzyme, mRNA, and enzymatic activity have been documented in human breast cancer cell lines and the rise in FASN is thought to be essential for evoking the malignant effects of proliferation and survival although this alone is not the reason for malignancy [71]. Thus elevated basal lipolysis followed by increased plasma levels of free fatty acids (FFAs) leads to enhanced intracellular accumulation which can impair non-adipose cells in their normal role as well as insulin signalling and the phenomenon is known as "lipotoxicity" [72].

\section{Obesity induced immunosuppression}

Obesity induces chronic, low-grade inflammation leading to increased levels of local and systemic proinflammatory cytokines including prostaglandin E2 (PG E2), tumour necrosis factor-alpha (TNF-a), interleukin (IL-2, IL-8, IL-10), C-reactive protein (CRP) and monocyte chemoattractant protein (MCP-1). In this context activation of NF-kB complex may be cited as a possible mechanism by which inflammation may stimulate cancer progression $[24,25]$. Thus, the proinflammatory state evident in the metabolic cells of adipocyte and the recruitment of immune cells along with the consequent release of inflammatory cytokines (TNF-a, IL-6, adiponectin etc.) is the outcome of obesity.

Tumour necrosis factor- $a$ or TNF- $a$

A pro-inflammatory cytokine by nature TNF-a exerts several effects in adipose tissue encompassing lipid metabolism and insulin signalling in which the circulating levels are elevated with obesity and levels off with weight loss. A rise in TNF-a stimulates the secretion of other pro-inflammatory cytokines like IL- 6 while decreasing the levels of anti-inflammatory cytokines like adiponectin [73]. Research findings indicated that TNF-a promoted adipocytes apoptosis and induced insulin resistance by means of inhibiting the insulin receptor substrate 1 signalling pathway $[74,75]$.

\section{Interleukin-6 or IL-6}

Macrophage is the preliminary source of circulating IL- 6 that plays a pivotal role in the whole-body energy homeostasis, as well as inflammation. The fact that IL- 6 has the potential to suppress the activity of lipoprotein lipase has been deduced from both in vitro and in vivo studies. Expression of IL-6 receptor is evident in certain brain regions and hypothalamus being one of them is responsible for controlling appetite and energy intake [76].

\section{Adiponectin}

Contrary to the reduced levels of adiponectin as seen in cases of animal models of obesity and insulin resistance, weight loss has been found to elevate the adiponectin levels. Regulation of lipid and glucose metabolism, increased sensitivity towards insulin, body weight and food intake regulation and protection against chronic inflammation are some of the vital roles of adiponectin [77].

Intracellular pathways of inflammation

Overfeeding has been hypothesized to be the starting signal of inflammation in obesity and the pathway has its inception in the metabolic cells like the adipocyte, hepatocyte or myocyte. Acute evocation of inflammatory responses due to consumption of nutrients has been suggested from studies in mice and humans $[78,79]$. Adipose tissue and liver in obese men and women, when compared to lean controls, exhibit hyperactivation of three kinases, namely: the c-jun $\mathrm{N}$-terminal kinase (JNK), the inhibitor of K kinase (IKK) and the protein kinase $R$ (PKR) capable of inducing inflammatory cytokines' expression $[80,81]$. The inflammasome and the Toll-like receptors (TLRs) of the innate immune system are activated as well in those same metabolic tissues $[82,83,84]$. Inflammatory signals or nutrients may trigger off the TLRs pathways and downstream JNK, IKK and PKR. These kinases control downstream transcriptional programs by means of the transcription factors activator protein-1 (AP-1), NF-KB and interferon regulatory factor (IRF) inducing upregulation of inflammatory mediator gene expression. The rise in cytokines aggravates receptor activation through a positive feedback loop of inflammation and the inhibitory signalling of metabolic pathways [85]. 


\section{Dysregulation in adipokines}

The adipose tissue, known primarily as energy storage organ, by virtue of recent studies has also been established as an endocrine organ, producing and secreting polypeptide hormones, adipokines, among which leptin and adiponectin are most common and involved in cancer development [86]. Adipokines (leptin, adiponectin and hepatocyte growth factor (HGF) are recognized for their participation in the mechanisms by which obesity and related metabolic disorders affect breast cancer risk [87]. The physiological and pathological communications of leptin and adiponectin are mostly antagonistic, as are their biological consequences on breast cancer cells [88].

Leptin, a hormone essentially exclusive to adipose tissue acts centrally in the hypothalamus for regulation of body weight and peripheral energy expenditure $[87,89]$. Circulating leptin levels are strongly correlated to the body fat content and are prominent in obese subjects to normal individuals $[90,91,92]$. Thus leptin, a potential mediator of obesity-related cancer influences cancer progression by activating PI3K, MAPK and STAT3 pathways, while the stimulatory effects of leptin on breast cancer growth were noted to occur primarily via oestrogen receptor activation [21, 26, 88, 93, 94]. Further, evidences through extensive research suggest that adiponectin, the most abundant adipokine, affect the proliferation and insulin sensitivity of various types of cells [95]. Unlike leptin, adiponectin is inversely related with adiposity, hyperinsulinaemia and inflammation [22]. Moreover, adiponectin may incur anticancer effects by diminishing insulin/ insulin like growth factor (IGF-1) and mTOR signalling via activation of 5 ' AMP-activated protein kinase (AMPK) and providing antiinflammatory action by the inhibition of nuclear factor kappa-light chain enhancer of activated $B$ cells (NF-KB) [22]. Current findings indicate that the low serum adiponectin levels are significantly associated with an increased risk for breast cancer and that tumours arising in women with the low serum adiponectin levels have greater likelihood of expressing a biologically aggressive phenotype [95]. Another adipokine, hepatocyte growth factor (HGF) or 'scatter factor' may exert a positive influence on tumorigenesis as a consequence of its antiangiogenic properties but is mainly known for its ability to promote cell invasion [88]. Numerous investigations revealed that the serum concentration of HGF are often elevated in patients with breast cancer and particularly so in those suffering from the advanced disease stage $[96,97,98]$.

\section{Conclusions}

The striking association between obesity and incidence of breast cancer has been established through several investigations and experiments until date. The various metabolic and endocrine mechanisms that account for the pathogenesis of obesity linked breast cancer have been discussed here to further probe into the nodal points of control in these cascades that may be beneficial to the researchers for generation of novel and effective therapeutic interventions for combating the ailment along with positive lifestyle modifications. Currently hormonal therapy with selective estrogen receptor modulators (SERMs) (such as tamoxifen and raloxifene) as well as aromatase inhibitors (such as exemastane, anastrozole, and letrozole) has been approved as standard mode of treatment of women with estrogen receptor-positive breast cancer. This therapy alongside adjuvant therapy acts in curing of advanced disease form though issues relating to their side effects are also a major concern $[99,100]$. The efficacy of another drug which acts as an insulin lowering agent named metformin, in reducing breast cancer recurrence is presently being studied extensively $[101,102,103]$. Simultaneously in the recent years Yoga based lifestyle interventions that is a form of physical activity facilitating in accomplishing recommended levels of physical fitness have gained much attention and are found to effectively thwart and hinder the progression of cardiovascular and metabolic syndromes like that of obesity $[104,105]$. The method of action of such benefit may be credited to a reduction in weight and stress, networking at mind and body levels, thereby leading to a decline in inflammation, and causation and progression of the disease [106]. Thus, any further information about the drugs and other treatment modalities that can ameliorate the adverse effects of breast cancer by altering the markers of obesity may also be useful in this regard.

\section{Acknowledgements}

The authors would like to express their heartfelt gratitude towards the works of researchers whose findings and reports have played integral roles in preparing this review. 


\title{
ОЖИРІННЯ - ФАКТОР РИЗИКУ РАКУ МОЛОЧНОЇ ЗАЛОЗИ
}

\author{
A. S. Roy, S. Basu, A. Bandyopadhyay \\ UNIVERSITY OF CALCUTTA, UNIVERSITY COLLEGE OF SCIENCE AND TECHNOLOGY, \\ KOLKATA, WEST BENGAL, INDIA
}

Вступ. Ожиріння - це глобальна проблема здоров'я, що набула значної поширеності зі зміною сучасного способужиття. Також це незалежний прогностичний фактор розвитку раку молочної залози, особливо у жінок в період постменопаузи.

Мета огляду - комплексний аналіз біохімічних, гормональних та імунологічних чинників, які пов'язують ожиріння з раком молочної залози, та пошук потенційних методів лікування.

Методи дослідження. Аналіз даних літератури для оцінки поточного стану проблеми.

Результати. Надмірна вага, та головним чином накопичення вісцерального жиру, пов'язані з підвищеним ризиком розвитку злоякісних захворювань, однак механізми їх розвитку значно варіюють залежно від ураженого органу. Обговорюються метаболічні та біохімічні показники, що впливають на канцерогенез, пов'язаний з ожирінням; включно з розвитком оксидативного стресу та ознак запального процесу з одночасним підвищенням рівня прозапальних цитокінів. А також такі фактори як підвищений рівень сироваткового інсуліну, інсуліноподібного фактора росту, статевих стероїдів та дисбалансу адипокінів (адипонектину і лептину).

Висновки. Переконливі докази вказують на ожиріння як незалежний прогностичний фактор розвитку раку молочних залоз, особливо у жінок після менопаузи. Розробка нових ефективних терапевтичних заходів для лікування раку та модифікація стилю життя можуть забезпечити позитивні зрушення.

КЛЮЧОВІ СЛОВА: ожиріння; рак молочної залози; ліпотоксичність; адипонектини.

\section{References}

1. World Health Organization, Special Programme for Research, Training in Tropical Diseases, World Health Organization. Department of Control of Neglected Tropical Diseases, World Health Organization. Epidemic, Pandemic Alert. Dengue: guidelines for diagnosis, treatment, prevention and control. World Health Organization; 2009.

2. Peter T, Kuo Hadlay L, Conn Eugene A, DeFelice. Health \& Obesity. Lippincott-Raven Publishers; 1983: 2

3. Bianchini $F$, Kaaks R, Vainio $H$. Overweight, obesity, and cancer risk. The lancet oncology. 2002 Sep 1;3(9):565-74.

4. Josefson D. Obesity fuels cancer epidemic. British Medical Journal, 2001: 322: 945.

5. McCann J. Obesity, cancer links prompt new recommendations. Journal of the National Cancer Institute. 2001 Jun 20;93(12):901-2.

6. World Health Organization. Obesity: preventing and managing the global epidemic. World Health Organization; 2000.

7. James PT. Obesity: the worldwide epidemic. Clinics in dermatology. 2004 Jul 1;22(4):276-80.

8. Manson JE, Willett WC, Stampfer MJ, Colditz GA, Hunter DJ, Hankinson SE, et al. Body weight and mortality among women. New England Journal of Medicine, 1995:333:677-85.

9. IARC. Weight Control and Physical Activity. IARCPress, Lyon, 2002.

10. Ceschi M, Gutzwiller F, Moch H, Eichholzer M, Probst-Hensch NM. Epidemiology and pathophy- siology of obesity as a cause of cancer. Swiss medical weekly. 2007 Jan 27;137(3/4):50.

11. McPherson K, Steel MC, Dixon MJ. Breast cancer-epidemiology, risk factors, and genetics. British Medical Journal, 2000. 21:1-5.

12. Pischon T, Nöthlings, Boeing H. Symposium on 'Diet and cancer' Obesity and cancer. Proceedings of the Nutrition Society, 2008:67:128-145.

13. Rossen L, Rossen E. Obesity 101. Springer Publishing Company; 2011 Sep 19.

14. Berrington de Gonzalez A, Hartge P, Cerhan JR, Flint AJ, Hannan L, MacInnis RJ, Moore SC, Tobias GS, Anton-Culver H, Freeman LB, Beeson WL. Body-mass index and mortality among 1.46 million white adults. New England Journal of Medicine. 2010 Dec 2;363(23):2211-9.

15. Calle EE, Kaaks R. Overweight, obesity and cancer: epidemiological evidence and proposed mechanisms. Nature Reviews Cancer. 2004 Aug; 4(8):579.

16. Van Kruijsdijk RC, van der Wall E, Visseren FL. Obesity and cancer: the role of dysfunctional adipose tissue. Cancer Epidemiology and Prevention Biomarkers. 2009 Sep 15:1055-9965.

17. International Agency for Research on Cancer. IARC handbooks of cancer prevention. The Agency; 2002.

18. World Cancer Research Fund, American Institute for Cancer Research. Food, nutrition, physical activity, and the prevention of cancer: a global perspective. Amer Inst for Cancer Research; 2007. 
19. Calle EE, Rodriguez C, Walker-Thurmond K, Thun MJ. Overweight, obesity, and mortality from cancer in a prospectively studied cohort of US adults. New England Journal of Medicine. 2003 Apr 24;348(17):1625-38.

20. Flegal KM, Carroll MD, Ogden CL, Curtin LR. Prevalence and trends in obesity among US adults, 1999-2008. Jama. 2010 Jan 20;303(3):235-41.

21. Drew JE. Molecular mechanisms linking adipokines to obesity-related colon cancer: focus on leptin. Proceedings of the Nutrition Society. 2012 Feb;71(1):175-80.

22. Dalamaga M, Diakopoulos KN, Mantzoros CS. The role of adiponectin in cancer: a review of current evidence. Endocrine reviews. 2012 Aug 1;33(4):547-94.

23. Gallagher EJ, LeRoith D. Minireview: IGF, insulin, and cancer. Endocrinology. 2011 May 3;152(7):2546-51.

24. Hursting SD, Berger NA. Energy balance, host-related factors, and cancer progression. Journal of Clinical Oncology. 2010 Sep 10;28(26):4058.

25. Harvey $A E$, Lashinger LM, Hursting SD. The growing challenge of obesity and cancer: an inflammatory issue. Annals of the New York Academy of Sciences. 2011 Jul 1;1229(1):45-52.

26. Chen J. Multiple signal pathways in obesityassociated cancer. Obesity reviews. 2011 Dec;12(12): 1063-70.

27. Ferlay J, Autier $\mathrm{P}$, Boniol M, Heanue M, Colombet M, Boyle P. Estimates of the cancer incidence and mortality in Europe in 2006. Annals of oncology. 2007 Feb 7;18(3):581-92.

28. Vera-Ramirez L, Ramirez-Tortosa MC, Sanchez-Rovira P, Ramirez-Tortosa CL, Granados-Principal S, Lorente JA, Quiles JL. Impact of diet on breast cancer risk: a review of experimental and observational studies. Critical reviews in food science and nutrition. 2013 Jan 1;53(1):49-75.

29. Hunter DJ, Willett WC. Epidemiology Review, 1993;15:110-132.

30. Ballard-Barbash R, Swanson CA. Body weight: estimation of risk for breast and endometrial cancers. The American journal of clinical nutrition. 1996 Mar 1;63(3):437S-41S.

31. Trentham-Dietz A, Newcomb PA, Storer BE, Longnecker MP, Baron J, Greenberg ER, Willett WC. Body size and risk of breast cancer. American journal of epidemiology. 1997 Jun 1;145(11):1011-9.

32. Galanis DJ, Kolonel LN, Lee J, Le Marchand L. Anthropometric predictors of breast cancer incidence and survival in a multi-ethnic cohort of female residents of Hawaii, United States. Cancer Causes \& Control. 1998 Mar 1;9(2):217-24.

33. Stoll BA. Breast cancer and the western diet: role of fatty acids and antioxidant vitamins. European Journal of Cancer. 1998 Nov 1;34(12):1852-6.

34. Bayley JP, Devilee P. Warburg tumours and the mechanisms of mitochondrial tumour suppressor genes. Barking up the right tree? Current opinion in genetics \& development. 2010 Jun 30;20(3):324-9.

35. Bayley JP, Devilee P. The Warburg effect in 2012. Current opinion in oncology. 2012 Jan 1;24(1): 62-7.
36. Amadou A, Hainaut $P$, Romieu I. Role of obesity in the risk of breast cancer: lessons from anthropometry. Journal of oncology. 2013;19.

37. Brown KA, Simpson ER. Obesity and Breast Cancer. Briefs in Cancer Research. Springer, 2014.

38. Rana S, Blowers EC, Natarajan A. Small molecule adenosine 5'-monophosphate activated protein kinase (AMPK) modulators and human diseases. Journal of medicinal chemistry. 2014 Aug 28; 58(1):2-9.

39. Kaaks R, Lukanova A. Energy balance and cancer: the role of insulin and insulin-like growth factor-I. Proceedings of the Nutrition Society. 2001 Feb;60(1):91-106.

40. Stoll BA. Breast cancer and the western diet: role of fatty acids and antioxidant vitamins. European Journal of Cancer. 1998 Nov 1;34(12):1852-6.

41. Fürstenberger G, Senn HJ. Insulin-like growth factors and cancer. The lancet oncology. 2002 May 1;3(5):298-302.

42. Gupta K, Krishnaswamy G, Karnad A, Peiris AN. Insulin: a novel factor in carcinogenesis. The American journal of the medical sciences. 2002 Mar 1;323(3):140-5.

43. Renehan AG, Zwahlen $M$, Minder $C T$, O'Dwyer S, Shalet SM, Egger M. Insulin-like growth factor (IGF)-I, IGF binding protein-3, and cancer risk: systematic review and meta-regression analysis. The Lancet. 2004 Apr 24;363(9418):1346-53.

44. Renehan AG, Frystyk J, Flyvbjerg A. Obesity and cancer risk: the role of the insulin-IGF axis. Trends in Endocrinology \& Metabolism. 2006 Oct 1;17(8):328-36.

45. Kaaks R, Lukanova A. Effects of weight control and physical activity in cancer prevention: role of endogenous hormone metabolism. Annals of the New York Academy of Sciences. 2002;963:268-81.

46. Harvie M, Renehan AG, Frystyk J, Flyvbjerg A, Mercer T, Malik R, Adams J, Cuzick J, Howell A. Increase in serum total IGF-I and maintenance of free IGF-I following intentional weight loss in pre-menopausal women at increased risk of breast cancer. The Open Obesity Journal. 2010;2(2):63-70.

47. Renehan AG. Epidemiology of overweight/ obesity and cancer risk. InPhysical activity, dietary calorie restriction, and cancer 2011 (pp. 5-23). Springer, New York, NY.

48. De Pergola G, Silvestris F. Obesity as a major risk factor for cancer. Journal of obesity. 2013 Aug 29;2013.

49. Frasca F, Pandini G, Sciacca L, Pezzino V, Squatrito $S$, Belfiore A, Vigneri R. The role of insulin receptors and IGF-I receptors in cancer and other diseases. Archives of physiology and biochemistry. 2008 Jan $1 ; 114(1): 23-37$

50. Vucenik I, Stains JP. Obesity and cancer risk: evidence, mechanisms, and recommendations. Annals of the New York Academy of Sciences. 2012 Oct;1271(1):37-43.

51. Spindler SR. Rapid and reversible induction of the longevity, anticancer and genomic effects of caloric restriction. Mechanisms of ageing and development. 2005 Sep 1;126(9):960-6. 
52. Imayama I, Ulrich CM, Alfano CM, Wang C, Xiao L, Wener MH, Campbell KL, Duggan C, FosterSchubert KE, Kong A, Mason CE. Effects of a caloric restriction weight loss diet and exercise on inflammatory biomarkers in overweight/obese postmenopausal women: a randomized controlled trial. Cancer research. 2012 May 1;72(9):2314-26.

53. Fine EJ, Segal-Isaacson CJ, Feinman RD, Herszkopf S, Romano MC, Tomuta N, Bontempo AF, Negassa A, Sparano JA. Targeting insulin inhibition as a metabolic therapy in advanced cancer: a pilot safety and feasibility dietary trial in 10 patients. Nutrition. 2012 Oct 1;28(10):1028-35.

54. Lagunova Z, Porojnicu AC, Grant WB, Bruland $\varnothing$, Moan JE. Obesity and increased risk of cancer: Does decrease of serum 25-hydroxyvitamin D level with increasing body mass index explain some of the association? Molecular nutrition \& food research. 2010 Aug;54(8):1127-33.

55. Hursting SD, Lashinger LM, Wheatley KW, Rogers CJ, Colbert LH, Nunez NP, Perkins SN. Reducing the weight of cancer: mechanistic targets for breaking the obesity-carcinogenesis link. Best practice \& research Clinical endocrinology \& meta bolism. 2008 Aug 1;22(4):659-69.

56. Key TJ, Verkasalo PK, Banks E. Epidemiology of breast cancer. The lancet oncology. $2001 \mathrm{Mar}$ $1 ; 2(3): 133-40$.

57. Weiss LK, Burkman RT, Cushing-Haugen KL, Voigt LF, Simon MS, Daling JR, Norman SA, Bernstein L, Ursin G, Marchbanks PA, Strom BL. Hormone replacement therapy regimens and breast cancer risk1. Obstetrics \& Gynecology. 2002 Dec 1;100(6):1148-58.

58. Van Leeuwen FE, Rookus MA. Breast cancer and hormone-replacement therapy: the million women study. Lancet, 2003; 362: 1330.

59. Ritte R, Lukanova A, Tjønneland A, Olsen A, Overvad K, Mesrine S, Fagherazzi G, Dossus L, Teucher B, Steindorf K, Boeing $\mathrm{H}$. Height, age at menarche and risk of hormone receptor-positive and -negative breast cancer: A cohort study. International journal of cancer. 2013 Jun 1;132(11):2619-29.

60. Chlebowski RT, Aiello E, McTiernan A. Weight Loss in Breast Cancer Patient Management. Journal of Clinical Oncology, 2002;20:1128-43.

61. Han W, Kim SW, Park IA, Kang D, Kim SW Youn YK, Oh SK, Choe KJ, Noh DY. Young age: an independent risk factor for disease-free survival in women with operable breast cancer. BMC cancer. 2004 Dec;4(1):82.

62. Renehan AG, Roberts DL, Dive C. Obesity and cancer: pathophysiological and biological mechanisms. Archives of physiology and biochemistry. 2008 Jan 1;114(1):71-83.

63. Travis RC, Key TJ. Oestrogen exposure and breast cancer risk. Breast Cancer Research. 2003 Oct;5(5):239.

64. Kaaks R, Rinaldi S, Key TJ, Berrino F, Peeters PH, Biessy C, Dossus L, Lukanova A, Bingham S, Khaw KT, Allen NE. Postmenopausal serum androgens, oestrogens and breast cancer risk: the European prospective investigation into cancer and nutrition. Endocrinerelated cancer. 2005 Dec 1;12(4):1071-82.
65. Key TJ, Vogel VG. Body mass index, serum sex hormones, and breast cancer risk in postmenopausal women. Breast Diseases. 2004;15(1):33-33.

66. Rinaldi S, Key TJ, Peeters $\mathrm{PH}$, Lahmann $\mathrm{PH}$, Lukanova A, Dossus L, Biessy C, Vineis P, Sacerdote C, Berrino F, Panico S. Anthropometric measures, endogenous sex steroids and breast cancer risk in postmenopausal women: a study within the EPIC cohort. International Journal of Cancer. 2006 Jun 1;118(11): 2832-9.

67. Potischman N, Swanson CA, Siiteri P, Hoover RN. Reversal of relation between body mass and endogenous estrogen concentrations with menopausal status. Journal of National Cancer Institute, 1996;88:756-758.

68. Boyd NF, Lockwood GA, Byng JW, Tritchler DL, Yaffe MJ. Mammographic densities and breast cancer risk. Cancer Epidemiology and Prevention Biomarkers. 1998 Dec 1;7(12):1133-44.

69. Hunt DA, Lane HM, Zygmont ME, Dervan PA, Hennigar RA. MRNA stability and overexpression of fatty acid synthase in human breast cancer cell lines. Anticancer research. 2007 Jan 1;27(1A):27-34.

70. Louie SM, Roberts LS, Nomura DK. Mechanisms linking obesity and cancer. Biochimica Et Biophysica Acta (bba)-Molecular And Cell Biology Of Lipids. 2013 Oct 31;1831(10):1499-508.

71. Menendez JA, Lupu R. Fatty acid synthase and the lipogenic phenotype in cancer pathogenesis. Nature Reviews Cancer. 2007 Oct;7(10):763.

72. Rajala MW, Scherer PE. Minireview: the adipocyte - at the crossroads of energy homeostasis, inflammation, and atherosclerosis. Endocrinology. 2003 Sep 1;144(9):3765-73.

73. Wang B, Trayhurn P. Acute and prolonged effects of TNF-a on the expression and secretion of inflammation-related adipokines by human adipocytes differentiated in culture. Pflügers Archiv. 2006 Jul 1;452(4):418-27.

74. Prins JB, Niesler CU, Winterford CM, Bright NA, Siddle K, O'rahilly S, Walker NI, Cameron DP. Tumor necrosis factor-a induces apoptosis of human adipose cells. Diabetes. 1997 Dec 1;46(12):1939-44.

75. Hotamisligil GS, Peraldi P, Budavari A, Ellis R, White MF, Spiegelman BM. IRS-1-mediated inhibition of insulin receptor tyrosine kinase activity in TNF-aand obesity-induced insulin resistance. Science. 1996 Feb 2;271(5249):665-70.

76. Stenlöf K, Wernstedt I, Fjällman T, Wallenius V, Wallenius $K$, Jansson JO. Interleukin- 6 levels in the central nervous system are negatively correlated with fat mass in overweight/obese subjects. The Journal of Clinical Endocrinology \& Metabolism. 2003 Sep 1;88(9):4379-83.

77. Liu M, Liu F. Transcriptional and post-translational regulation of adiponectin. Biochemical Journal. 2010 Jan 1;425(1):41-52.

78. Watt MJ, Hevener A, Lancaster GI, Febbraio MA. Ciliary neurotrophic factor prevents acute lipidinduced insulin resistance by attenuating ceramide accumulation and phosphorylation of c-Jun N-terminal kinase in peripheral tissues. Endocrinology. 2006 May 1;147(5):2077-85. 
79. Aljada A, Mohanty P, Ghanim H, Abdo T, Tripathy D, Chaudhuri A, Dandona P. Increase in intranuclear nuclear factor $\mathrm{KB}$ and decrease in inhibitor KB in mononuclear cells after a mixed meal: evidence for a proinflammatory effect. The American journal of clinical nutrition. 2004 Apr 1;79(4):682-90.

80. Solinas G, Karin M. JNK1 and IKKß: molecular links between obesity and metabolic dysfunction. The FASEB Journal. 2010 Aug;24(8):2596-611.

81. Nakamura T, Furuhashi M, Li P, Cao H, Tuncman G, Sonenberg N, Gorgun CZ, Hotamisligil GS. Double-stranded RNA-dependent protein kinase links pathogen sensing with stress and metabolic homeostasis. Cell. 2010 Feb 5;140(3):338-48.

82. Schroder K, Zhou R, Tschopp J. The NLRP3 inflammasome: a sensor for metabolic danger? Science. 2010 Jan 15;327(5963):296-300.

83. Shi H, Kokoeva MV, Inouye $\mathrm{K}$, Tzameli I, Yin $\mathrm{H}$, Flier JS. TLR4 links innate immunity and fatty acidinduced insulin resistance. The Journal of clinical investigation. 2006 Nov 1;116(11):3015-25.

84. Song MJ, Kim KH, Yoon JM, Kim JB. Activation of Toll-like receptor 4 is associated with insulin resistance in adipocytes. Biochemical and biophysical research communications. 2006 Aug 4;346(3):739-45.

85. Boura-Halfon S, Zick Y. Phosphorylation of IRS proteins, insulin action, and insulin resistance. American Journal of Physiology-Endocrinology and Metabolism. 2009 Apr;296(4):E581-91.

86. Kershaw EE, Flier JS. Adipose tissue as an endocrine organ. The Journal of Clinical Endocrinology \& Metabolism. 2004 Jun 1;89(6):2548-56.

87. Friedman JM, Halaas JL. Leptin and the regulation of body weight in mammals. Nature. 1998 Oct;395(6704):763.

88. Vona-Davis L, Rose DP. Adipokines as endocrine, paracrine, and autocrine factors in breast cancer risk and progression. Endocrine-related cancer. 2007 Jun 1;14(2):189-206.

89. Flier JS. What's in a name? In search of leptin's physiologic role. The Journal of Clinical Endocrinology \& Metabolism. 1998 May 1;83(5):1407-13.

90. Rosenbaum MI, Nicolson MA, Hirsch JU, Heymsfield SB, Gallagher DY, Chu FL, Leibel RL. Effects of gender, body composition, and menopause on plasma concentrations of leptin. The Journal of Clinical Endocrinology \& Metabolism. 1996 Sep 1;81(9):3424-7.

91. Maffei M, Halaas J, Ravussin E, Pratley RE, Lee $\mathrm{GH}$, Zhang Y, Fei H, Kim S, Lallone R, Ranganathan S, Kern PA. Leptin levels in human and rodent: measurement of plasma leptin and ob RNA in obese and weight-reduced subjects. Nature medicine. 1995 Nov;1(11):1155.

92. Lönnqvist F, Arner P, Nordfors L, Schalling M. Overexpression of the obese (ob) gene in adipose tissue of human obese subjects. Nature medicine. 1995 Sep;1(9):950.

93. Gao J, Tian J, Lv Y, Shi F, Kong F, Shi H, Zhao L. Leptin induces functional activation of cyclooxyge- nase-2 through JAK2/STAT3, MAPK/ERK, and PI3K/ AKT pathways in human endometrial cancer cells. Cancer science. 2009 Mar;100(3):389-95.

94. Jaffe T, Schwartz B. Leptin promotes motility and invasiveness in human colon cancer cells by activating multiple signal-transduction pathways. International Journal of Cancer. 2008 Dec 1;123(11): 2543-56.

95. Miyoshi Y, Funahashi T, Kihara S, Taguchi T, Tamaki Y, Matsuzawa Y, Noguchi S. Association of serum adiponectin levels with breast cancer risk. Clinical cancer research. 2003 Nov 15;9(15):5699-704.

96. Toi M, Taniguchi T, Ueno T, Asano M, Funata N, Sekiguchi K, Iwanari H, Tominaga T. Significance of circulating hepatocyte growth factor level as a prognostic indicator in primary breast cancer. Clinical cancer research. 1998 Mar 1;4(3):659-64.

97. Sheen-Chen SM, Liu YW, Eng HL, Chou FF. Serum levels of hepatocyte growth factor in patients with breast cancer. Cancer Epidemiology and Prevention Biomarkers. 2005 Mar 1;14(3):715-7.

98. Taniguchi T, Toi M, Inada K, Imazawa T, Yamamoto Y, Tominaga T. Serum concentrations of hepatocyte growth factor in breast cancer patients. Clinical Cancer Research, 1995;1:1031-1034.

99. Kaplan W, Wirtz V, Mantel A, Béatrice PS. Priority Medicines for Europe and the World Update 2013 report. Methodology. 2013 May 29;2(7).

100. Last Medical Review. Breast Cancer. American Cancer Society, 2014;1-127.

101. DeCensi A, Puntoni M, Goodwin P, Cazzaniga M, Gennari A, Bonanni B, Gandini S. Metformin and cancer risk in diabetic patients: a systematic review and meta-analysis. Cancer prevention research. 2010 Oct 12:1940-6207.

102. Goodwin PJ, Ligibel JA, Stambolic V. Metformin in breast cancer: time for action. Journal of clinical oncology: official journal of the American Society of Clinical Oncology. 2009 Jul 10;27(20):3271.

103. Jiralerspong S, Palla SL, Giordano SH, MericBernstam F, Liedtke C, Barnett CM, Hsu L, Hung MC, Hortobagyi GN, Gonzalez-Angulo AM. Metformin and pathologic complete responses to neoadjuvant chemotherapy in diabetic patients with breast cancer. Journal of clinical oncology. 2009 Jul 10; 27(20):3297.

104. Shinde N, Shinde KJ, Khatri SM, Hande D. A comparative study of yoga and aerobic exercises in obesity and its effect on pulmonary function. J Diabetes Metab. 2013;4(257):2.

105. Sarvottam K, Yadav RK. Obesity-related inflammation \& cardiovascular disease: Efficacy of a yoga-based lifestyle intervention. The Indian journal of medical research. 2014 Jun;139(6):822.

106. Stewart ST, Cutler DM, Rosen AB. Forecasting the effects of obesity and smoking on US life expectancy. New England Journal of Medicine. 2009 Dec 3;361(23):2252-60.

Received: 2018-08-16 